\title{
Effect of Sodium Bicarbonate as a Buffer Feeding on Milk Yield and Fat Percent of Dairy Crossbred Cows
}

\author{
Sunil Singh $^{1}$, Jayant Kashyap ${ }^{2}$, Neeraj ${ }^{3}$ and Ramesh Pandey ${ }^{3}$ \\ ${ }^{1}$ ICAR- Krishi Vigyan Kendra, Unnao-229881 (UP), India \\ ${ }^{2}$ Central Bank of India, Jalgaon-425306 (Maharashtra), India \\ ${ }^{3}$ SSAH \& Dairying, SHUATS, Allahabad-211007 (UP), India \\ *Corresponding author
}

\begin{tabular}{|l|}
\hline Ke y w o r d s \\
$\begin{array}{l}\text { Buffer feeding } \\
\left(\mathrm{NaHCO}_{3}\right), \text { Dairy } \\
\text { cattle, Milk } \\
\text { composition, Milk } \\
\text { yield }\end{array}$ \\
\hline Article Info \\
\hline $\begin{array}{l}\text { Accepted: } \\
\text { 26 October } 2018 \\
\text { Available Online: } \\
\text { 10 November } 2018\end{array}$ \\
\hline
\end{tabular}

A B S T R A C T

The dairy farming in our country is entirely different from other developed countries. The reason is that small and marginal farmers feeding of dairy animals produce the bulk of production in our country. In terms of buffer use in nutrition, it has been defined as a salt of a weak acid which neutralizes acids that occur in feeds or acids produced during digestion and metabolism of nutrients. The experiment was carried out on 16 healthy crossbred cows nearly similar age and in late stage lactation to study the effect of feeding buffer on milk yield and fat per cent of raw milk. Four groups of buffer feeding were adopted in the study viz., concentrate mixture (control), concentrate mixture with $1 \%$, $1.5 \%$ and $2 \%$ of $\mathrm{NaHCO}_{3}$ (Sodium bicarbonate). All cows were kept under same feeding schedule for 9 days under preliminary period to adapt the test diet followed by 28 days experimental period for records, and fed ration wheat straw and concentrate. The data on milk yield and composition of milk were analyzed through statistics using, analysis of variance technique. The data on mean value of Total solids, Fat per cent and Solid not fat per cent were significantly $(\mathrm{P}<0.05)$ higher in Group IV followed by Groups III, II and I, however specific gravity and milk yield $(\mathrm{kg})$ were not significantly different between the groups. Based on these finding $2 \%$ of $\mathrm{NaHCO}_{3}$ was significantly at the level of $(\mathrm{P}<0.05)$ superior compared to control, $1 \%$ and $1.5 \%$ of $\mathrm{NaHCO}_{3}$

\section{Introduction}

Animal husbandry culture in India initiated long back since medieval times which determines the status of family and prosperity of nation representing the particular civilization. In terms of buffer use in nutrition, it has been defined as a salt of a weak acid/hydroxide/oxide which neutralizes acids that occur in feeds or acids produced during digestion and metabolism of nutrients (Chalupa and Schneider, 1985). For a compound to be effective as a buffer under physiological conditions, it must be water soluble, be a weak acid, base or salt thereof have a $\mathrm{pKa}$ value near the physiological $\mathrm{pH}$ of the system to be buffered (Murphy, 1992). The buffering capacity of carbonates, such as 
sodium bicarbonate, is based on equilibrium between $\mathrm{HCO}_{3}, \mathrm{H}^{+}, \mathrm{H}_{2} \mathrm{CO}_{3}, \mathrm{CO}_{2}$ and $\mathrm{H}_{2} \mathrm{O}$ as follow: $\mathrm{CO}_{2}+\mathrm{H}_{2} \mathrm{O} \leftrightarrow \mathrm{H}_{2} \mathrm{CO}_{3} \leftrightarrow \mathrm{H}^{+}+\mathrm{HCO}_{3}$

Bicarbonate ion $\left(\mathrm{HCO}_{3}^{-}\right)$is a normal constituent of the blood and it's produced by the reaction of carbon dioxide $\left(\mathrm{CO}_{2}\right)$ with water $\left(\mathrm{H}_{2} \mathrm{O}\right)$ to produce carbonic acid $\left(\mathrm{H}_{2} \mathrm{CO}_{3}\right)$, which dissociates to a bicarbonate ion $\left(\mathrm{HCO}_{3}{ }^{-}\right)$and a proton $\left(\mathrm{H}^{+}\right)$. When the concentration of $\mathrm{H}^{+}$increases, the equilibrium shifts towards the right, which results in a buffering effect. It is generally recognized that milk fat depression is the result of a reduction in the ratio of lipogenic to glucogenic volatile fatty acids (VFA), promoted by the fermentation of such diets. Characteristics of this fermentation pattern include a reduction in the molar proportion of acetate and an increase in the molar proportion of propionate and rumen acidity, and a simultaneous lowering of the buffering capacity of the rumen fluid (Counotte et al., 1979). It is now generally accepted that the addition of buffers, such as sodium bicarbonate $\left(\mathrm{NaHCO}_{3}\right)$, to low fibre diets will help prevent or alleviate milk fat depression (Staples and Lough 1989). Furthermore, while the systemic buffering properties of $\mathrm{NaHCO}_{3}$ have been investigated (Erdman et al., 1982), few studies have attempted to contrast acid-base metabolism and milk production in cows fed $\mathrm{NaHCO}_{3}$ to those maintained in a state of metabolic acidosis. Such work is required to demonstrate the value of $\mathrm{NaHCO}_{3}$, as a systemic buffer and to document any potential benefits such buffering properties may have on production and productivity. The objective of present study was to compare separate level of $\mathrm{NaHCO}_{3}$ of roughage and concentrate i.e. concentrate mixture (control), concentrate mixture along with $1 \%, 1.5 \%$ and $2 \%$ of lactating crossbred cattle in India and to examine the effect of $\mathrm{NaHCO}_{3}$ on productive performance such as milk fat, total solids and SNF of lactating crossbred cow.

\section{Materials and Methods}

\section{Experiment design}

The experiment was conducted at the dairy farm of the Sam Higginbottom University of Agriculture, Technology \& Sciences, Allahabad to determine the effect of the four feeding groups on compositional quality of milk and milk yield in crossbred cattle. It is situated on an altitude of 89 metre (320 feet) above elevation, latitude and longitude position being $25.413^{\circ} \mathrm{N}$ and $81.849^{\circ} \mathrm{E}$ respectively. Minimum ambient temperature is recorded near $9^{\circ} \mathrm{C}$ in winter, and maximum temperature goes up to $36^{\circ} \mathrm{C}$ in summer with annual rainfall of $1025 \mathrm{~mm}$. For the present study, sixteen crossbred lactating cows were selected from the dairy farm of SHUATS, Allahabad. These animals were further divided equally into four groups (4 cows in each group) i.e. concentrate mixture as a control (group I), concentrate mixture with $1.0 \%$ (group II), 1.5\% (group III) and $2.0 \%$ (group IV) of $\mathrm{NaHCO}_{3}$ (Sodium bicarbonate), Initial body weight of crossbred cows were $421.46 \pm 4.26 \mathrm{~kg}$. The mass of nearly similar age and stage of lactation were selected for the study. All cows were kept under same feeding schedule for 9 days under preliminary period to adapt the test diet followed by 28 days experimental period for record of data.

\section{Feeding and management of animals}

The experimental animals were kept in separate pens throughout the study. The concentrate mixture and straw (Table 1) were offered in the morning (10:00 AM). Cows were fed individually to meet the requirements (Kearl, 1982) on respective diets.

\section{Milk sample analysis}

Daily milk production of each cow was recorded and weighted through digital 
balance. Milk samples, consisted of proportional volumes of morning milk were taken after cleaning and disinfection of teats and discarding the first streams of foremilk. Milk samples were collected in $100 \mathrm{ml}$ sterile plastic vials at last consecutive 10 days through the lactation period and taken to the laboratory. Specific gravity was determined in milk sample by using Lactometer according to Murphy (1999), Total solids was done by Badcock's formula according to Prasad et al., (1999), Fat percent was determined in milk samples by using Gerber's method according to BIS (1977), Solid not fat was calculated according to Prasad et al., (1999) and Milk yield of cows was recorded daily in morning at 4.00 to 5.00 am and afternoon at 2.00 to $3.00 \mathrm{pm}$.

\section{Statistical analysis}

The data on milk yield and its composition were analyzed statistically using one way ANOVA technique as per Snedecor and Cochran (1994). Means were separated for significance by using Tukey Kramer range tests.

\section{Results and Discussion}

The results of all parameters are showed in Table 2. The highest specific gravity was recorded in group IV (1.0378) followed by groups III (1.0368), II (1.0370) and I (1.0368), respectively. The differences in these values were found non-significant between the groups but numerically higher in groups. The results of specific gravity of the study are in the line with the observation of Counotte et al., (1979), who has reported that nonsignificant difference between the groups.

The highest total solid in milk of cows were registered highest in group IV (15.677) followed by groups III (14.185), II (13.294) and I (12.852). The differences in these values of total solids were found significant $(\mathrm{P}<0.05)$ in between the groups. This clearly indicates that feeding of buffer has significant effect on total solid percent of milk. These results are in agreement with $\mathrm{Xu}$ and Harrison (1994). The highest fat percent was recorded in group IV (5.167) followed by groups III (4.160), II (3.348) and I (3.015).

The differences in these values were found significant $(\mathrm{P}<0.05)$ indicating thereby a significant effect of treatments on fat percent. This indicates that feeding of buffer has significant effect on fat per cent of milk. These results are in agreement with Harrison et al., (1989), who has reported that feeding buffer has affected fat percent in result. The average highest solid not fat (SNF) percent was recorded in group IV (10.497) followed by groups III (10.024), II (9.945) and I (9.845).

The differences in these values were founded significant $(\mathrm{P}<0.05)$ indicating thereby a significant effect of treatments on SNF percent. However, these indicate no significant difference found groups III and II being at par. This indicates the feeding of buffer has significantly higher in SNF in milk of cows. Results of SNF per cent of the study are in agreement with Xu and Harrison (1994). The average milk yield $(\mathrm{kg} / \mathrm{d})$ was recorded in group IV (5.54) followed by groups III (5.33), II (4.74) and I (3.13). The differences in these values were founded non-significant differences in between among groups.

The result of milk yield of the study is agreement with Rogers and Muller (1985), who has reported that feeding of buffer results in decrease in milk yield having inverse effect. Hence, feeding of buffer has non-significant effect on milk yield of cows. The main parameters Milk yield and Fat percent were graphical presentation in Figure 1, which was shown the effect of buffer feeding in 
Table.1 Feed ingredients and chemical composition used in the experimental ration

\begin{tabular}{|l|c|c|}
\hline \multicolumn{1}{|c|}{ Chemical Composition } & Concentrate mixture & Wheat straw \\
\hline Dry matter \% & $88.97 \pm 0.60$ & $89.785 \pm 0.29$ \\
\hline CP \% & $10.47 \pm 0.22$ & $3.10 \pm 0.11$ \\
\hline Ether extract \% & $2.59 \pm 0.06$ & $1.04 \pm 0.04$ \\
\hline CF \% & $16.49 \pm 0.13$ & $39.41 \pm 0.26$ \\
\hline NFE \% & $64.04 \pm 0.61$ & $45.61 \pm 0.54$ \\
\hline TA \% & $6.41 \pm 0.45$ & $10.84 \pm 0.68$ \\
\hline *TDN \% & $69.77 \pm 0.88$ & $47.31 \pm 0.61$ \\
\hline
\end{tabular}

*Total Digestible Nutrient calculated by NRC, 1989.

Table.2 Milk yield and its composition of lactating crossbred cows fed Sodium bicarbonate $\left(\mathrm{NaHCO}_{3}\right)$ as a buffer feeding

\begin{tabular}{|l|c|c|c|c|c|}
\hline \multicolumn{1}{|c|}{ Parameters } & Group IV & Group III & Group II & Group I & Result \\
\hline Specific gravity & 1.03788 & 1.03681 & 1.03702 & 1.0368 & NS \\
\hline Total solids (\%) & $15.677^{\mathbf{a}}$ & $14.185^{\mathbf{b}}$ & $13.294^{\mathbf{c}}$ & $12.852^{\mathbf{d}}$ & S \\
\hline Milk fat (\%) & $5.167^{\mathbf{a}}$ & $4.160^{\mathbf{b}}$ & $3.348^{\mathbf{c}}$ & $3.015^{\mathbf{d}}$ & $\mathrm{S}$ \\
\hline Solid not fat (\%) & $10.497^{\mathbf{a}}$ & $10.024^{\mathbf{b}}$ & $9.945^{\mathbf{b}}$ & $9.845^{\mathbf{c}}$ & S \\
\hline Milk yield (kg/d) & 5.545 & 5.336 & 4.740 & 3.133 & NS \\
\hline
\end{tabular}

Figure.1 Graphical presentation of fat percent and milk yield during experiment

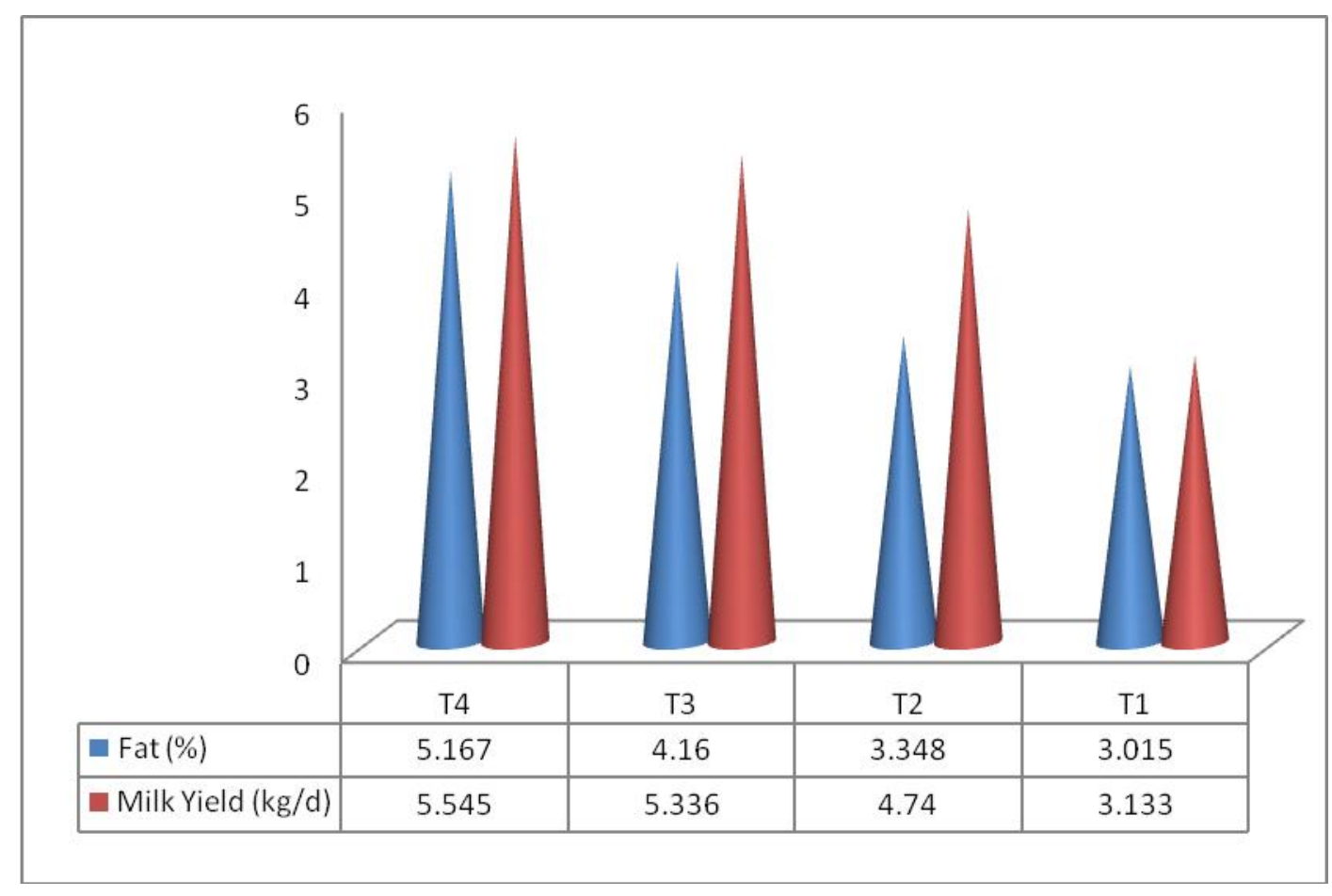


From this experiment and observation of the data, it may be concluded that buffer feeding in dairy animals found to be beneficial because it has significant effect on milk fat, total solids and solid not fat percent which are the important parameters in fixing the price of milk in markets as well as in cooperatives and private sectors.

\section{Acknowledgement}

Authors are greatly thankful to Vice Chancellor, Sam Higginbottom University of Agriculture, Technology and Sciences, Allahabad for providing necessary facilities during the course of investigation. The financial assistance for the research was provided by Sundereson school of Animal husbandry \& Dairying, SHUATS, Allahabad

\section{References}

BIS. 1977. Fat determination by Gerber method part-I (fat revision) 1224 (part-i) 1977. Bureau of Indian standard, Indian standard Institute mark Bhawan-9B.S.Z. Marg, New Delhi.

Chalupa, W. and Schneider, P. L. 1985. Buffers for dairy cattle. In Proc. Pacific NW Nutr. Conf., Boise, Idaho.

Counotte, G. H. M., Van't Klooster, A. Th., Van der Kuilen, J. and Prins, R. A. 1979. An analysis of the buffer system in the rumen of dairy cattle. Journal of Animal Science, 49: 1536-1544.

Erdman, R. A., Hemken, R. W. and Bull, L. S. 1982. Dietary sodium bicarbonate and magnesium oxide for early postpartum lactating dairy cows: Effects on production, acid-base metabolism, and digestion. Journal of Dairy Science, 65: 712-731.

\section{How to cite this article:}

Sunil Singh, Jayant Kashyap, Neeraj and Ramesh Pandey. 2018. Effect of Sodium Bicarbonate as a Buffer Feeding on Milk Yield and Fat Percent of Dairy Crossbred Cows. Int.J.Curr.Microbiol.App.Sci. 7(11): 3214-3218. doi: https://doi.org/10.20546/ijcmas.2018.711.369
Harrison, J. H., Riley, R. E. and Loney, K. A. 1989. Effect of type and amount of buffer addition to grass silage-based total mixed rations on milk production and composition. Journal of Dairy Science, 72: $1824-1830$.

Kearl, L. C. 1982. Nutrient Requirements of Ruminants in Developing Countries. 1st Edn. International Feedstuffs Institute, Utah State University, Logan, Utah, USA.

Murphy, J. J. 1999. The effect of increasing the proportion of molasses in the diet of milking dairy cows on milk production and composition. Animal Feed Science Technology. 78: 189-198.

Murphy, M.R. 1992. Symposium: nutritional factors affecting animal water and waste quality. Journal of Dairy Science, 75: 326-333.

Prasad, J., Neeraj and Tyagi, A. K. 1999. Principles and Practices of Animal Nutrition, Kalyani Publisher, Ludhiana.

Rogers, J. A., Muller, L. D., Snyder, T. J. and Maddox, T. L. 1985. Milk production, nutrient digestion, and rate of digesta passage in dairy cows fed long or chopped alfalfa hay supplemented with sodium bicarbonate. Journal of Dairy Science, 68: 868-880.

Snedecor, G. W. and Cochran, W. G. 1994. Statistical Methods. Iowa State University Press, Ames, Iowa, USA.

Staples, C. R. and Lough, D. S. 1989. Efficiency of supplemental dietary neutralizing agents for lactating dairy cows. A review. Animal Feed Science and Technology, 23: 277-303.

Xu, S., Harrison, J. H., Riley, R. E. and Loney, K. A. 1994. Effect of buffer addition to high grain total mixed rations on rumen $\mathrm{pH}$, feed intake, milk production, and milk composition. Journal of Dairy Science, 77: 782-788. 